\title{
Tectonostratigraphic terranes within Archaean gneiss complexes: examples from Western Australia and southern West Greenland
}

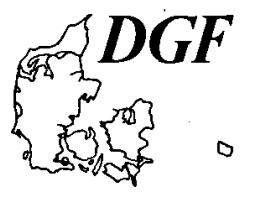

\begin{abstract}
Nutman, A. P.: Tectonostratigraphic terranes within Archaean gneiss complexes: examples from Western Australia and southern West Greenland. Bull. geol. Soc. Denmark, vol. 39, pp. 199-211. Copenhagen, December 20th, 1991. https://doiorg/10.37570/bgsd-1991-39-09

New field work and isotopic data show that the Godthåbsfjord region of West Greenland consists of a collage of tectonostratigraphic terranes, which evolved separately prior to tectonic juxtaposition in the late Archaean. In Western Australia the Narryer Gneiss Complex, which lies on the northwestern margin of the Yilgarn Craton, is, unlike the Godthåbsfjord region, very poorly exposed (less than $1 \%$ ). In consequence it is impossible to follow geological boundaries in this complex, and instead the complex has been studied by a very extensive use of within-grain zircon U-Pb geochronology on the ion microprobe SHRIMP. The zircon geochronology suggests that the Narryer Gneiss Complex also consists of several discrete terranes of early to mid Archaean gneisses. In both the Godthåbsfjord region and the Narryer Gneiss Complex, late Archaean juxtaposition of terranes was accompanied by intrusion of crustallyderived granites, deformation, and amphibolite facies metamorphism. Thus some Archaean high grade gneiss complexes consist of terranes that underwent independent evolution until they were brought together at a later time. In this respect their anatomy resembles post-Archaean orogenic belts that formed as a consequence of plate tectonic processes.
\end{abstract}

Allen P. Nutman, Research School of Earth Sciences, Australian National University, G.P.O. Box 4, Canberra ACT 2601, Australia. June 8th, 1990.

\section{Introduction: CADS and terranes}

The purpose of this paper is to review the lines of evidence supporting the application of the tectonostratigraphic terrane concept (sensu Coney, Jones \& Monger 1980) to the Archaean evolution of the Godthåbsfjord region, and then demonstrate how this concept has been applied to the early Archaean Narryer Gneiss Complex of Western Australia. Implications of recognition of tectonostratigraphic terranes in Archaean gneiss complexes for the evolution of the crust are then discussed.

In the late 1970s and early 1980s crustal accretion differentiation superevents (CADS) were recognised as the most important factor in the production of Archaean sialic crust (see e.g. Wells 1979, 1980; Moorbath \& Taylor 1986). From uncertainties on $\mathrm{Rb}-\mathrm{Sr}$ and $\mathrm{Pb}-\mathrm{Pb}$ whole rock dating (e.g. Moorbath \& Pankhurst 1976; Taylor et al. 1980), CADS took less than $\sim 200$ million years. The first phase (crustal accretion) of a CADS involves injection of predominantly trondhjem- itic and tonalitic magma into supracrustal sequences dominated by mafic rocks; older continental crust may or may not be present. These trondhjemitic and tonalitic rocks are now preserved as the "grey gneisses" ubiquitous in Archaean high grade gneiss complexes. Whole rock $\mathrm{Rb}-\mathrm{Sr}, \mathrm{Sm}-\mathrm{Nd}$ and $\mathrm{Pb}$ isotopic studies (see e.g. Taylor et al. 1980; Moorbath \& Taylor 1986; Moorbath et al. 1986) demonstrated that the protoliths of these grey gneisses are dominated by juvenile additions to the crust. The second phase (differentiation) of a CADS involves ultrametamorphism and partial melting in the depth of the new crust to give rise to a geochemically stratified crust by the extraction from the lower crust of granitic melt and LIL elements (see e.g. Fyfe 1973; Wells 1979). Following a CADS the new crust is stable and may survive for a long time.

The intensive studies in the 1970s of the Godthåbsfjord region, southern West Greenland, gave rise to much of the data which was first used to formulate the idea of CADS. The proposed mid Archaean CADS in the Godthåbsfjord re- 


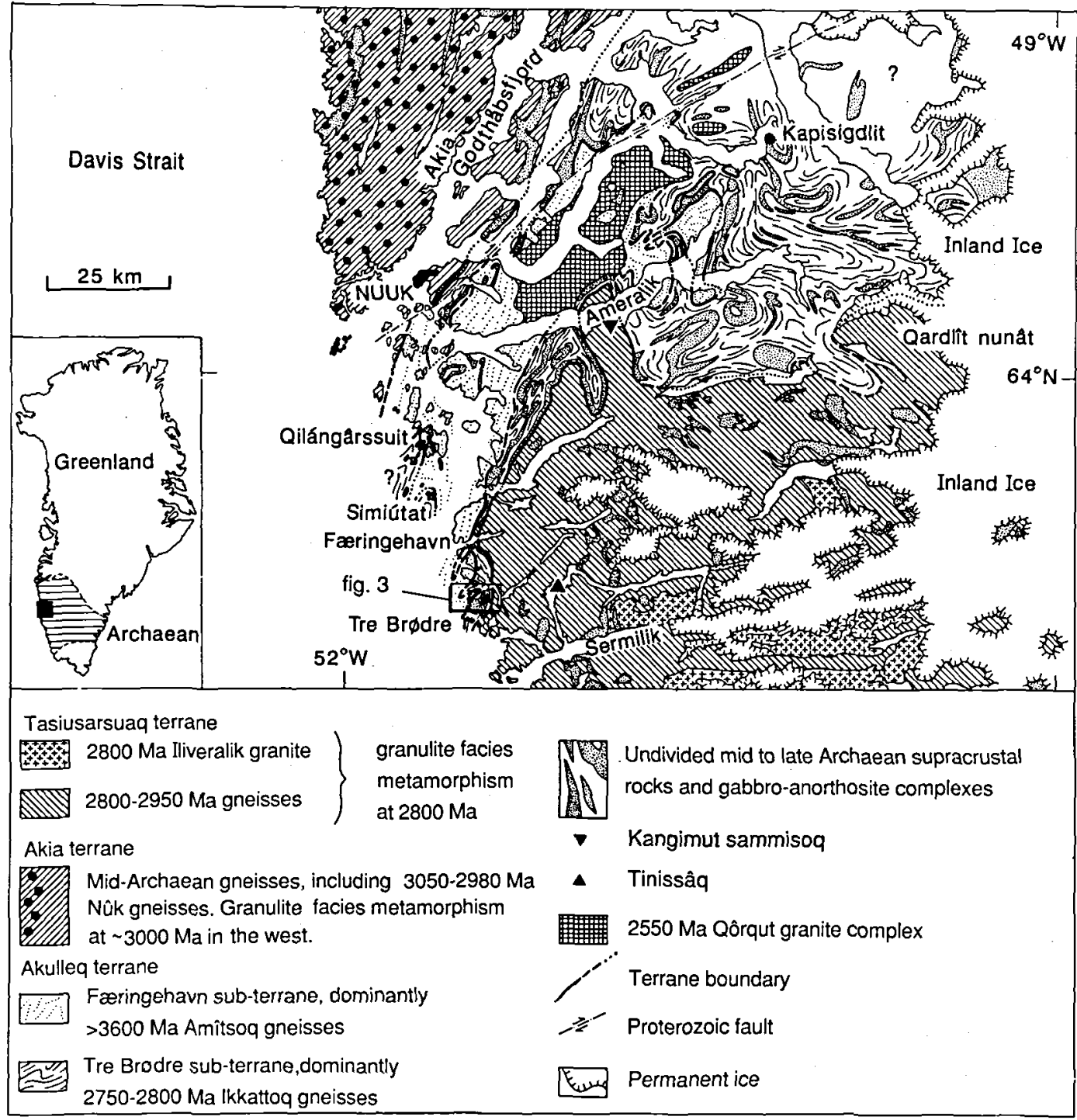

Fig. 1. Geological sketch map of the Godthåbsfjord region, West Greenland.

gion entailed (1) tectonic intercalation of the "Malene supracrustal rocks" and the early Archaean Amîtsoq gneisses (cut by the Ameralik dykes), (2) intrusion of the voluminous protoliths of the (type) Nûk gneisses of Nuuk and southwestern Godthåbsfjord and what were presumed to be their equivalents elsewhere in the region, and (3) folding and granulite facies metamorphism (see e.g. McGregor 1973, 1979; Bridgwater et al. 1974; Chadwick \& Nutman 1979; Wells 1979; Coe 1980; McGregor et al. 1983, 1986; Dymek 1984; Robertson 1986; Moorbath et al. 1986). Wells $(1976,1979)$ interpreted the granu- lite and amphibolite facies assemblages found in the southern half of the region as having formed at different structural levels during a single 2800 Ma metamorphic peak. Coe (1980) interpreted this purported synchronous regional metamorphic peak as marking "cratonisation" at $2800 \mathrm{Ma}$ following a CADS. Late Archaean shearing, granite emplacement and retrogression were regarded as evidence of local reworking of crust formed in a single mid Archaean CADS, rather than evidence of a much more complex crustal evolution for the Godthåbsfjord region (Bridgwater et al, 1976; McGregor et al. 1983). 


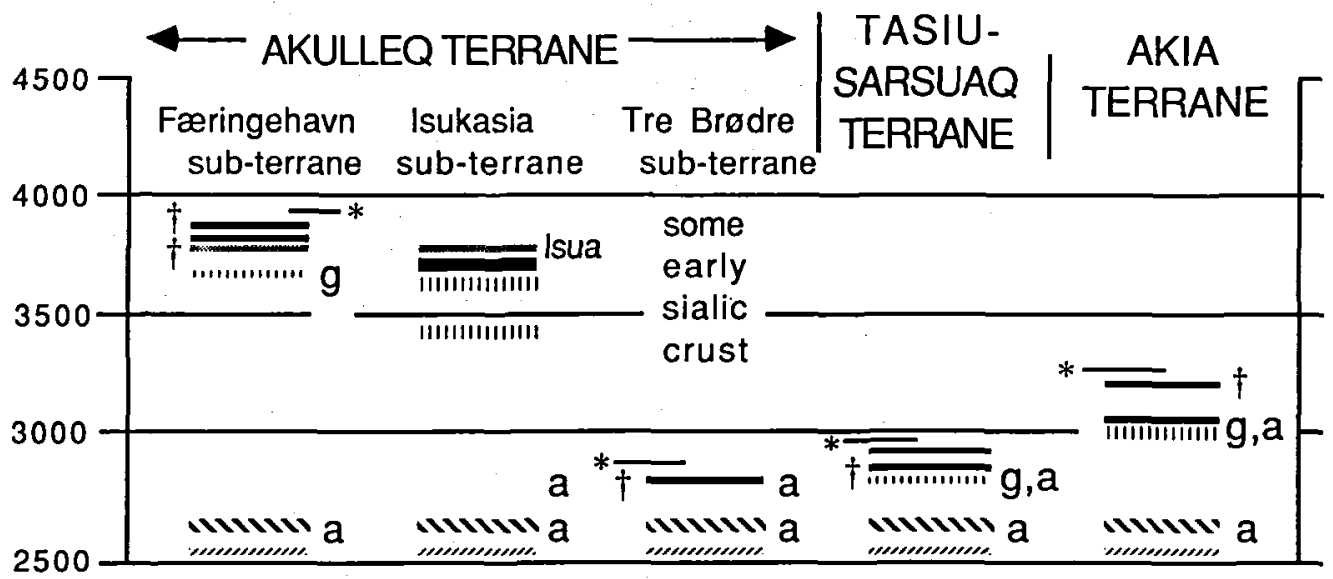

(Ma)

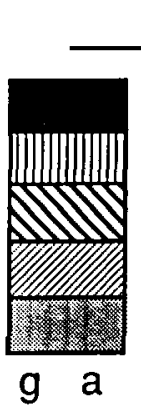

* stratigraphic position of supracrustal rocks not yet dated protoliths of Archaean grey gneisses granite unique to a terrane

$\uparrow$ unpublished SHRIMP results deformed granites found in several terranes Qôrqut granite complex and pegmatites, mostly undeformed dated supracrustal rocks documented granulite (g) and amphibolite (a) facies metamorphism

Fig. 2. Terrane chronology in the Godthåbsfjord region. †H. Baadsgaard, M.J. Duke and A.P. Nutman, unpublished SHRIMP within-grain zircon $\mathrm{U} \cdot \mathrm{Pb}$ data.

In the mid 1980s C.R.L. Friend, V.R. McGregor and the writer carried out remapping of selected areas in order to resolve the limit of Archaean granulite facies metamorphism and the extent of the early Archaean Amitsoq gneisses. The data gathered during this work showed that several associations of rocks are present in the Godthåbsfjord region, each with its own early history (Friend et al. 1987). Furthermore, "Nûk gneisses" dominating different associations with contrasting structural and metamorphic history, are now known from $\mathrm{U}-\mathrm{Pb}$ zircon geochronology to be of different ages (Nutman et al. 1989; Schiøtte et al. 1989; H. Baadsgaard, pers. comm.). This suggested that the region did not develop during a single CADS, and that it might instead consist of a collage of tectonostratigraphic terranes (sensu Coney et al. 1980) that were assembled in the late Archaean with amphibolite facies metamorphism, folding, and emplacement of crustally derived granites (Fig. 2). The Akia terrane and Tasiusarsuaq terrane, to the north and south of Godthåbsfjord respectively, are dominated by mid Archaean gneisses (Fig. 1). The Akulleq terrane, which forms most of Godthåbsfjord and the coastal strip south of Nuuk, contains a wide variety of rocks, ranging from early to late Archaean in age (McGregor et al. 1991 - this volume). The Akulleq terrane is a conglomeration of the Tre Brødre and Færingehavn terranes described in previous publications (e.g. Nutman et al. 1989), which are now reduced to sub-terrane status. The reason for this is that although tectonic boundaries have been identified between the Tre Brødre and Færingehavn sub-terranes (Friend et al. 1987), these sub-terranes contain the same lithologies but in different proportions. This is discussed by McGregor et al. (1991 - this volume).

\section{The Godthåbsfjord region}

The evidence for tectonostratigraphic terranes in the Godthåbsfjord region is demonstrated by results from part of the Færingehavn - Tre Brødre 


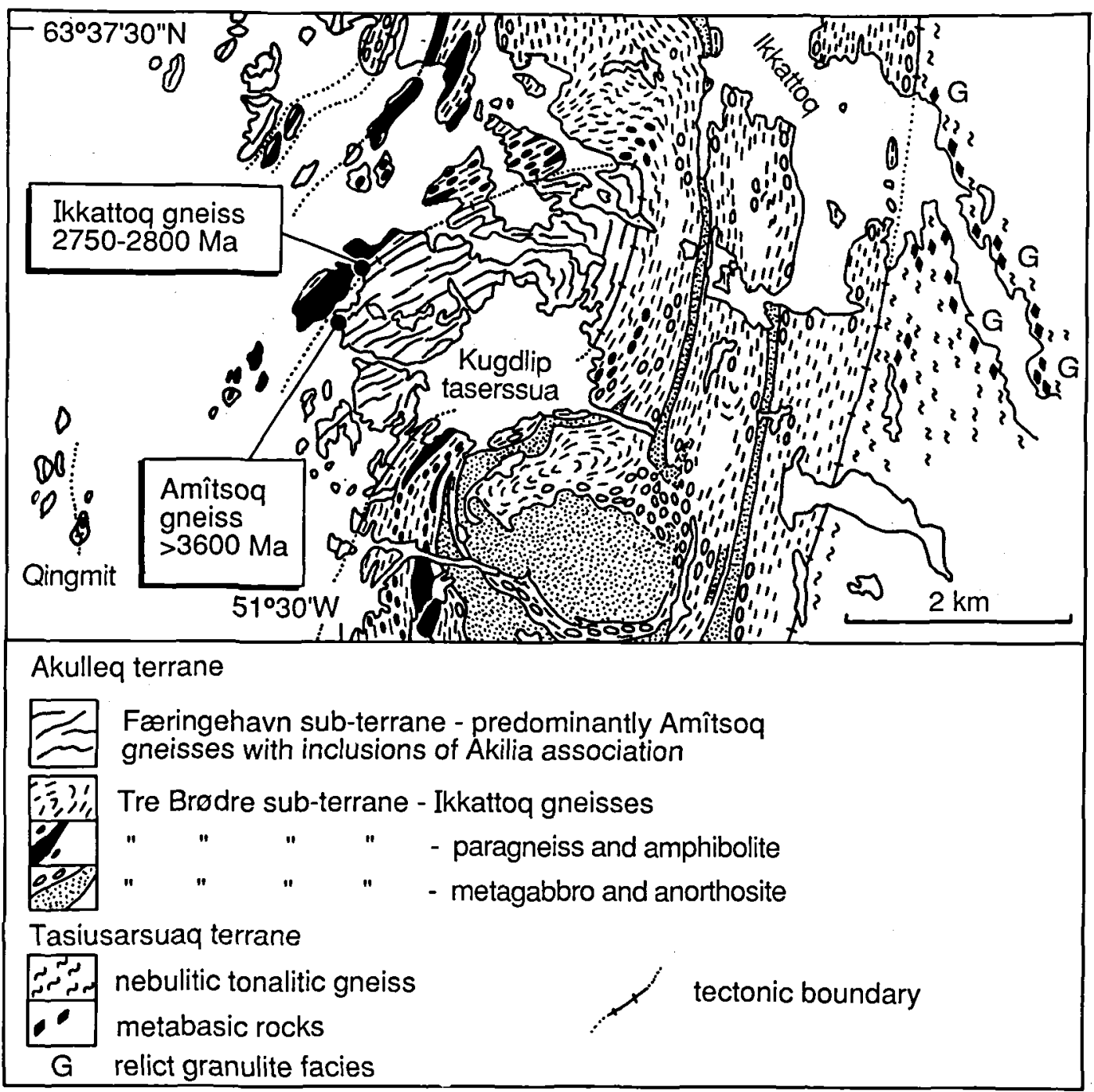

Fig. 3. Detailed map of part of the Færingehavn-Tre Brødre area, West Greenland, illustrating evidence for tectonostratigraphic terranes.

area as shown in Fig. 3. The eastern terrane in this area contains the controversial "old gneisses" at Tinissâq and Kangimut sammissoq (see Schiøtte et al. 1989 and McGregor et al. $1991-$ this volume - for discussion). Three lines of evidence to support the tectonostratigraphic terrane model for the region are considered here: structural, isotopic and metamorphic.

\section{Structural evidence}

The contacts between the terranes are zones of amphibolite facies fine-grained, flaggy rocks, less than $20 \mathrm{~m}$ wide, which are locally discordant to lithological units within the terranes (Fig 3; Friend et al. 1987). The zones of flaggy rocks separating the terranes consist of finely-layered quartzo-feldspathic and quartz-rich rocks, micaand amphibole-rich schistose rocks, and (locally discordant) seams of fuchsite-bearing quartz rocks. The schistose rocks commonly contain thin, disrupted pegmatitic veins. Small-scale rootless folds and sheath folds are commonly present within the flaggy rocks of the contact zones between the terranes, and are similar to structures described from other high-strain zones (e.g. 

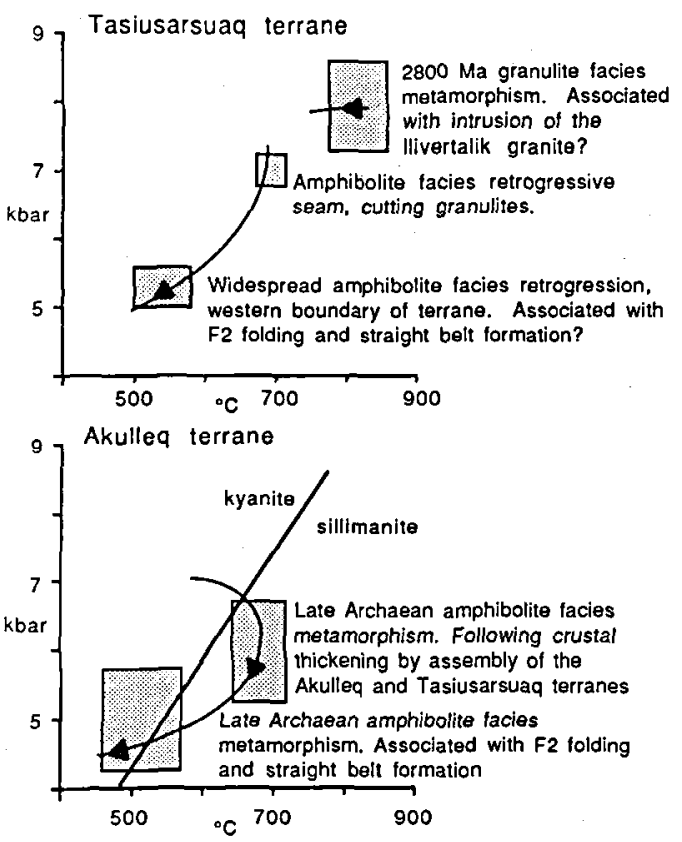

Fig. 4. P,T,t paths for the Tre Brødre sub-terrane of the Akulleq terrane and the Tasiusarsuaq terrane.

Cobbold \& Quinquis 1980). Many of the finegrained flaggy rocks have mylonitic to ultramylonitic textures (cf. Sibson 1977). From Figs 1 and 3 it is evident that these strongly deformed rocks between the terranes must be shear zones, and that they were subsequently folded. Further LS fabric development during later folding under amphibolite facies metamorphism has overprinted any kinematic indicators of the movement in the shear zones when they originally formed. These shear zones are now generally steeply dipping, but this is the result of rotation associated with later deformation.

\section{Isotopic evidence}

Gneisses from the part of the coastal region of the Færingehavn-Tre Brødre area shown in Fig. 3 have been dated by conventional bulk-zircon techniques by $\mathrm{H}$. Baadsgaard (in Nutman et al. 1989). The amphibolite facies, banded, tonalitic gneisses cut by amphibolite dykes forming most of the Færingehavn sub-terrane (Fig. 3) are early Archaean in age (Nutman et al. 1989), and are grouped with the type Amitsoq gneisses. The Færingehavn sub-terrane containing the Amîtsoq gneisses is in tectonic contact in this area with the
Tre Brødre sub-terrane which is dominated by amphibolite facies, rather homogeneous granodioritic "Nûk" gneisses with sparse pegmatite banding and devoid of amphibolite dykes, which are now named the Ikkattoq gneisses (Friend et al. 1988; Fig. 3). U-Pb conventional bulk-zircon dating of the Ikkattoq gneisses has yielded slightly discordant data with ${ }^{207} \mathrm{~Pb} /{ }^{206} \mathrm{~Pb}$ ages between 2790 and $2760 \mathrm{Ma}$ (Nutman et al. 1989). SHRIMP (Sensitive High Resolution Ion MicroProbe) within-grain zircon U-Pb dating of Ikkattoq gneisses throughout Godthåbsfjord has yielded concordant ages of $\sim 2820 \mathrm{Ma}(\mathrm{H}$. Baadsgaard and A.P. Nutman, unpublished data). Thus the Ikkattoq gneisses are considerably younger than the type Nûk gneisses $(\sim 3000$ $\mathrm{Ma}$ ) of south-west Godthåbsfjord. A protolith age of $\sim 2920 \mathrm{Ma}$ was obtained for granulite facies gneisses inland at Tinissâq in the Tasiusarsuaq terrane (Fig. 1) by Schiøtte et al. (1989) using SHRIMP. $\sim 2800$ Ma ages obtained on massive low-U overgrowths and recrystallised domains were interpreted as the age of the granulite facies metamorphism. Moreover, possible indications of an intermediate $\sim 2850$ Ma event were seen in this study.

\section{Metamorphic evidence}

Metamorphic evidence supporting the division of the Godthåbsfjord region into tectonostratigraphic terranes comes from contrasting time of maximum metamorphism and differing $P, T, t$ (pressure, temperature, time) paths for the terranes. Examples of these can be taken from the part of the Færingehavn-Tre Brødre area shown in Fig. 3. Geothermobarometry studies on rocks from the Tasiusarsuaq terrane in the east shows that it underwent granulte facies metamorphism with near isobaric cooling from the metamorphic peak (Wells 1979; Bohlen 1987; Nutman et al. 1989). From the SHRIMP zircon geochronology of low-U zircon overgrowths, this event has been established at $\sim 2800 \mathrm{Ma}$ (P. Kinny, pers. comm. 1987; Schiøtte et al. 1989). Retrogression of the granulites in the Tasiusarsuaq terrane is extensive near its tectonic contact with the Tre Brødre terrane (McGregor et al. 1986; Friend et al. 1988; Nutman et al. 1989). Geothermobarometry of retrogressed granulite facies rocks showed that retrogression of them occurred in two or more 


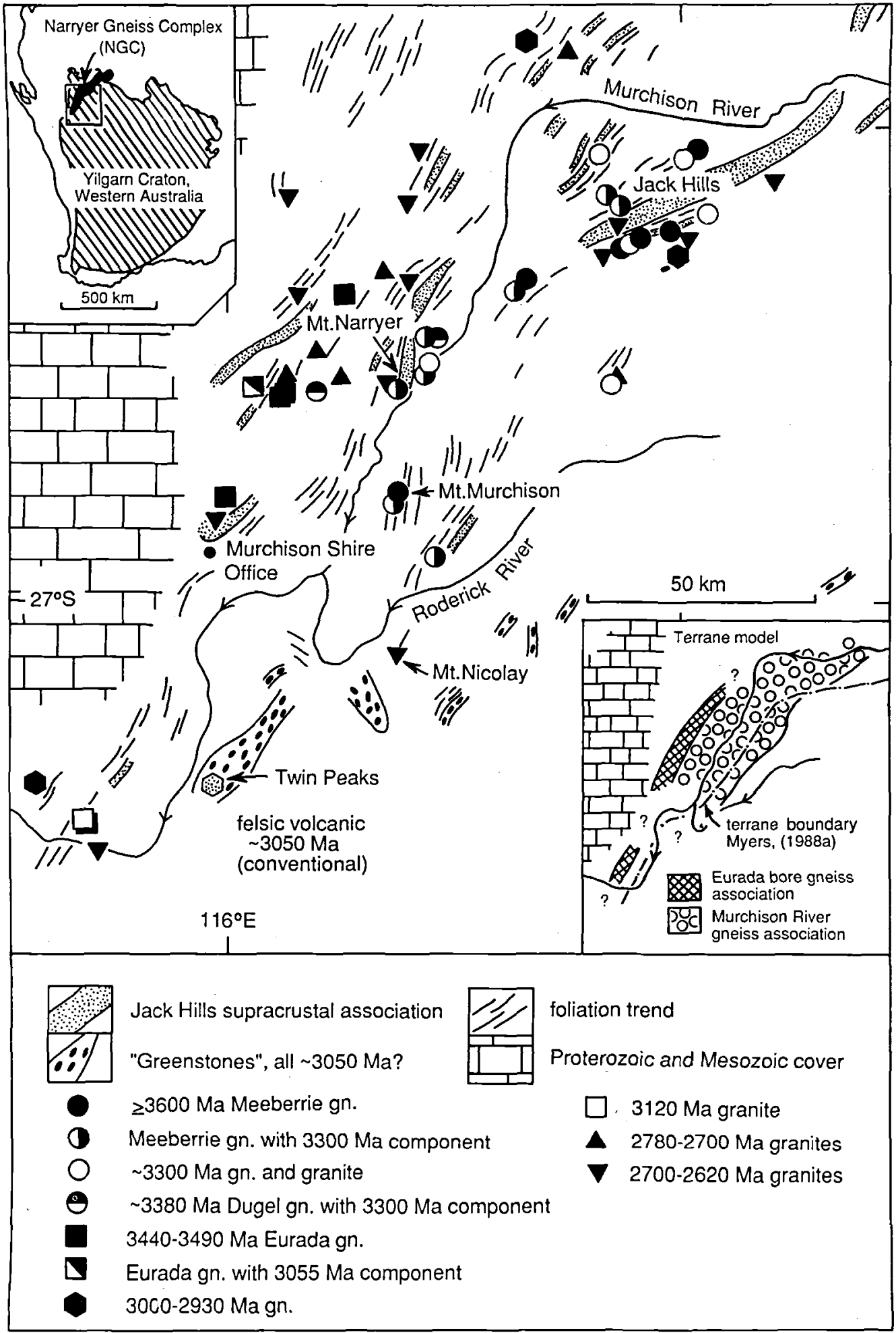

Fig. 5. Geochronological map of the Narryer Gneiss Complex and adjacent regions, Western Australia. All age determinations are by SHRIMP within-grain U-Pb geochronology, apart from conventional zircon geochronology of the Twin Peaks felsic volcanic rocks (Pidgeon 1986). 
stages under amphibolite facies conditions (Nutman et al. 1989). From these results an anticlockwise $\mathrm{P}, \mathrm{T}, \mathrm{t}$ path could be constructed for the Tasiusarsuaq terrane in the late Archaean (Fig. 4). On the other hand, geothermobarometry studies of rocks from the adjacent Tre Brødre sub-terrane of the Akulleq terrane (data in Wells 1979; Nutman et al. 1989) showed that they had never experienced granulite facies metamorphism and that these rocks followed a clockwise $\mathrm{P}, \mathrm{T}, \mathrm{t}$ path in the late Archaean (Fig. 4). The chronology for this region (Fig. 2) shows that the recorded peak metamorphism in the Akulleq terrane must have occurred later than the $\sim 2800$ Ma granulite facies metamorphism in the Tasiusarsuaq terrane. The contrasting $P, T, t$ path in the Tasiusarsuaq and Akulleq terranes could be the consequence of thrusting of the Tasiusarsuaq terrane over the Akulleq terrane, which would be in accord with the regional mapping of these units (Friend' $e t$ al. 1988). Therefore, the granulites of the Tasiusarsuaq terrane could have undergone retrogression and decompression associated with rapid erosion after thrusting, whilst the Akulleq terrane would have initially undergone compression and then heating due to burial associated with the thrusting event, which would have been followed by decompression and some cooling associated with subsequent erosion (Fig. 4).

\section{The Narryer Gneiss Complex}

The Narryer Gneiss Complex (Fig. 5) is the most northerly unit of $>2900$ Ma rocks in the western and northern margins of the Yilgarn Craton, named the Western Gneiss Terrane by Gee et al. (1981). The Narryer Gneiss Complex is bounded to the west and east by late to mid Archaean "granite-greenstone" complexes. Its boundaries are not exposed, or are obscured by late Archaean granites. To the north the Narryer Gneiss Complex is progressively reworked in the mid Proterozoic Capricorn orogen, and is also obscured by early Proterozoic metasediments and granites (Williams 1986). Within the Narryer Gneiss Complex exposure amounts to less than $1 \%$ of the area. Due to the lack of exposure, most important geological boundaries are not exposed. The gneisses that make up the complex are polyphase, and have undergone repeated high grade metamorphism and heterogeneous ductile deformation. Therefore gneisses of different ages can be hard to distinguish in the field. Because of these problems, unravelling of the history of the Narryer Gneiss Complex has relied heavily on extensive within-grain U-Pb geochronology using SHRIMP. The SHRIMP geochronological data presented in this review have been produced by several members of the "First Billion Years" project at Australian National University, lead by Professor W. Compston. Altogether, over 2000 zircons from more than 70 rocks have been analysed from the Narryer Gneiss Complex. More detailed discussion of these data are given by Froude et al. (1983), Compston \& Pidgeon (1986), Kinny (1987), Kinny et al. (1988, 1990) and Nutman et al. (in press). The technique for $\mathrm{U}-\mathrm{Pb}$ isotopic analysis of zircons using SHRIMP is given by Compston $e t$ al. (1984) with recent modifications described by Kinny et al. (1990).

Within the Narryer Gneiss Complex, the Meeberrie gneiss and the Dugel gneiss were recognised by a combination of field studies and $\mathrm{Sm}-\mathrm{Nd}$ and $\mathrm{Rb}-\mathrm{Sr}$ whole rock geochronology (Myers \& Williams 1985; Williams \& Myers 1987; Myers 1988a). Meeberrie gneisses in the vicinity of Mt Narryer have yielded Sm-Nd model ages ( $\mathrm{T}_{\text {CHUR }}$ ) of between 3710 and $3620 \mathrm{Ma}$ (De Laeter et al. 1981, 1985). Cores of zircons from a Meeberrie gneiss gave a weighted mean ${ }^{207} \mathrm{~Pb} /{ }^{206} \mathrm{~Pb}$ age of $3678 \pm 6 \mathrm{Ma}$ (Kinny et al. 1988). Samples of Dugel gneiss have yielded Sm-Nd model ages $\left(\mathrm{T}_{\text {CHUR }}\right.$ ) of between 3540 and $3510 \mathrm{Ma}$ (De Laeter et al. 1981; Fletcher et al. 1983), whilst cores of zircons in a Dugel gneiss have yielded a Concordia intercept age of $3381 \pm 22 \mathrm{Ma}$ (Kinny et al. 1988). Myers (1988a) regarded the Meeberrie and Dugel gneisses as by far the most abundant rocks in the Narryer Gneiss Complex. However, further extensive SHRIMP within-grain zircon geochronological studies show that gneisses of other ages are just as important (Kinny 1987; Kinny et al. 1990; Nutman et al. in press).

Metasedimentary rocks make up about 10 percent of the Narryer Gneiss Complex (Myers 1988a) and are found as concordant lenses intercalated with early Archaean gneisses. Some of the sediments contain a small subpopulation of $\sim$ $3050 \mathrm{Ma}$ detrital grains, therefore they must be younger than $3050 \mathrm{Ma}$ (Kinny et al. 1990). The 
largest metasedimentary units form Mt Narryer and Jack Hills and contain a small percentage of $4280-4100$ Ma grains in their detrital zircon populations (Froude et al. 1983; Compston \& Pidgeon 1986). The most common lithology of the sedimentary units is white to pale green fuchsitic quartzite, in which sedimentary structures have been obliterated by strong deformation. In areas of low deformation original structures such as cross-bedding are locally preserved (Williams \& Myers 1987). At both Jack Hills and Mt Narryer quartz pebble conglomerates occur (e.g. Williams \& Myers 1987; Compston \& Pidgeon 1986). The quartzites and conglomerates are found in association with pelitic schists and quartz + magnetite banded iron formation. There is little or no mafic or felsic volcanic material associated with these sediments. The sedimentary sequences were probably deposited on continental crust, in a shallow marine or fluviatile environment (Williams \& Myers 1987).

The gneisses and supracrustal rocks described above are intruded by voluminous leucocratic granites, which mostly occur as sheets and lenticular bodies. Several generations of these granites are present, with ages ranging between 2750 and 2600 Ma (De Laeter et al. 1985; Kinny et al. 1990). Many of the 2750 to 2600 Ma granites are markedly foliated, demonstrating that the observed amphibolite facies parageneses throughout the region and a significant amount of the observed deformation must be late Archaean or even younger.

Subdivision of the Narryer Gneiss Complex and adjacent parts of the region

To the west and east of the Narryer Gneiss Complex, granitic and tonalitic gneisses with ages of $3000 \mathrm{Ma}$ or less occur (Fig. 5). As yet, early Archaean rocks have not been found in these parts of the region. The early Archean gneisses seem to form a strip ca. $70 \mathrm{~km}$ wide within a mid to late Archaean gneiss complex. The early Archaean gneisses within the Narryer Gneiss Complex are divided into the Murchison Gneiss Association and the Eurada Gneiss Association. In addition the Jack Hills Supracrustal Association is also recognised (Nutman et al. in press).

The Murchison Gneiss Association occupies the eastern part of the Narryer Gneiss Complex, flanking the Murchison River. In this part of the complex Myers (1988a) recognised the Meeberrie and Dugel gneisses. The regional SHRIMP geochronological studies (see e.g. Nutman et al. in press) confirm that rocks of the same character and age (predominantly $\geq 3600$ components) as the type Meeberrie gneisses are quite common in this part of the region. However, it is now evident that this part of the complex contains volumetrically important $\sim 3300$ Ma gneisses (Fig. 5).

The Eurada Gneiss Association forms a strip within the Narryer Gneiss Complex and consists of a group of granitic gneisses, with protolith ages of between 3490 and $3440 \mathrm{Ma}$. In addition, one unit of $\sim 3120 \mathrm{Ma}$ granite has also been found (Fig. 5). $\sim 3300 \mathrm{Ma}$ granite and pegmatite veins, very common in the Murchison Gneiss Association, have not been found in this part of the Narryer Gneiss Complex. On the other hand, one Eurada Gneiss Association sample (Fig. 5) contains abundant $\sim 3055$ Ma pegmatitic material.

Further mapping and U-Pb zircon age geochronology of pelites, quartzites and banded iron formations throughout the full extent of the Narryer Gneiss Complex reveal that they are all lithologically similar and show a range of detrital zircon ages from 4280 to $\sim 3050 \mathrm{Ma}$. Because of the similar character of all these units, they are grouped in the Jack Hills Supracrustal Association. This supracrustal association coincides in extent with the early Archaean gneisses of the Narryer Gneiss Complex. On both sides of this: where only mid to late Archaean gneisses occur, supracrustal units are predominantly mafic to felsic volcanic rocks with banded iron formation (Fig. 5).

\section{Metamorphic history}

${ }^{40} \mathrm{Ar}-{ }^{39} \mathrm{Ar}$ and zircon ${ }^{207} \mathrm{~Pb} /{ }^{206} \mathrm{~Pb}$ geochronology shows that the whole of the Narryer Gneiss Complex and the adjacent regions were affected by one or more high grade metamorphic events in the late Archaean (Kinny et al. 1990; Nutman et al. in press). Prior to high grade metamorphism in the late Archaean, two other metamorphic events are apparent in the Narryer Gneiss Complex. First, the early Archaean gneisses of the Murchison Gneiss Association show widespread 

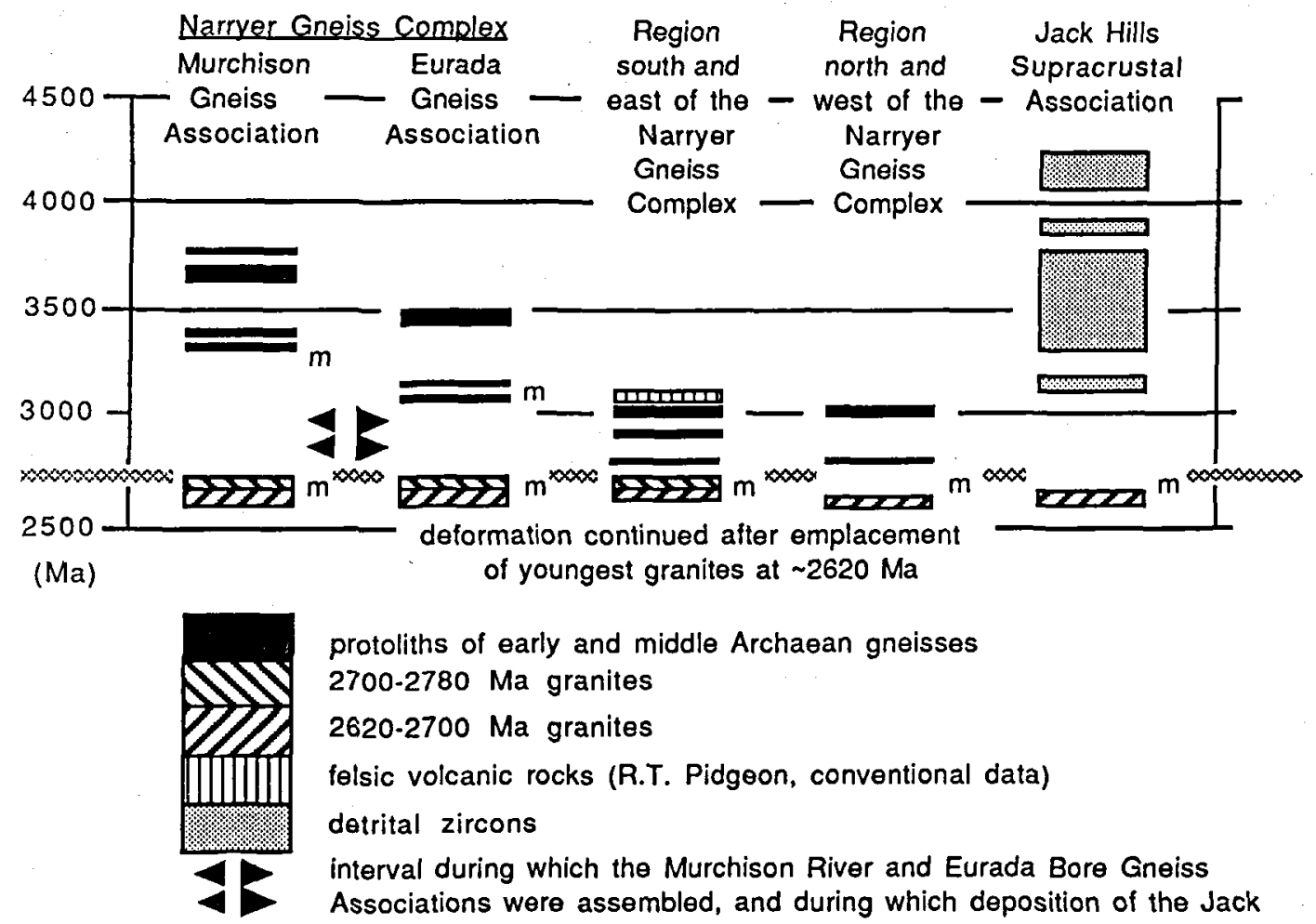

protoliths of early and middle Archaean gneisses

2700-2780 Ma granites

2620-2700 Ma granites

felsic volcanic rocks (R.T. Pidgeon, conventional data)

detrital zircons

interval during which the Murchison River and Eurada Bore Gneiss

Associations were assembled, and during which deposition of the Jack

Hills Supracrustal Association occurred

m documented metamorphism

Fig. 6. Terrane chronology of the Narryer Gneiss Complex and adjacent regions.

growth of zircons at $\sim 3300 \mathrm{Ma}$ (Fig. 5). This $3300 \mathrm{Ma}$ event is interpreted as the time of migmatisation and high grade metamorphism coincident with the emplacement of the youngest granites unique to this association (Myers 1988a; Nutman et al. in press). Second, in the Eurada Gneiss Association to the west, one sample shows clear evidence of zircon growth at $\sim 3055$ (Fig. 5).

It is probable that earlier events such as emplacement of voluminous protoliths of the Meeberrie gneisses in the Murchison Gneiss Association were accompanied by high grade metamorphism and deformation. However, because of the severity of subsequent tectonometamorphic events, evidence for the occurrence and nature of these events has been obliterated.
Recognition of terranes in the Narryer Gneiss Complex and adjacent regions

The Murchison Gneiss Association and the Eurada Gneiss Association would appear to have had separate early histories but in the Middle Archaean they had come into close proximity of each other, so that upon erosion they could together give rise to the detrital component in the Jack Hills Supracrustal Association, apart from the small proportion of detrital component derived from $>3800 \mathrm{Ma}$ rocks (Fig. 6). Detailed examination of the ages of detrital zircons within the Jack Hills Supracrustal Association shows that samples with a large proportion of zircons derived from rocks of the same age as the Meeberrie gneisses of the Murchison Gneiss Association are devoid of $>3800$ Ma detrital grains. This suggests that the source rocks of the $>3800$ Ma detrital grains are either within the Eurada Gneiss Association or in another gneiss unit per- 
haps preserved farther south in the Western Gneiss Terrane for which there are only meagre geochronological data. All outcrops of the Eurada Gneiss Association visited are devoid of material such as distinct inclusions which could be intact $>3800$ Ma rocks. Furthermore, some 200 zircons in the Eurada gneisses have now been analysed, and neither xenocrysts nor cores of $>3800$ Ma zircon have been found.

Although the detrital sediments in the Jack Hills Supracrustal Association were laid down on or in close proximity to the Murchison Gneiss Association, these supracrustal rocks now occur as tectonic intercalations with rocks of the two gneiss associations, some of which have been folded into synformal keels (Williams \& Myers 1987). Tectonic disruption and initial folding of the Jack Hills Supracrustal Association may have been coeval with the earliest known high grade metamorphic event that these rocks underwent, dated at $\sim 2700 \mathrm{Ma}$ by the ${ }^{40} \mathrm{Ar}-{ }^{39} \mathrm{Ar}$ method (Kinny et al. 1990).

From 2750 to $2620 \mathrm{Ma}$ the Narryer Gneiss Complex and the adjacent regions (with mid Archaean gneisses) have a common history (Fig. 6). Using the tectonostratigraphic terrane concept of Coney et al. (1980), these different entities are interpreted as tectonostratigraphic terranes which evolved separately prior to late Archaean tectonic juxtaposition (assembly), folding, high grade metamorphism, and intrusion of crustally derived granites. The late Archaean granites are commonly sheared close to the margins of the Narryer Gneiss Complex. This suggests that the boundaries of the associations (i.e. tectonostratigraphic terranes in the model proposed here) might be modified by late shear zones, unrelated to the actual assembly of the terranes at a somewhat earlier time.

\section{Discussion}

In the well exposed Godthåbsfjord region, crustal evolution has been studied by integrated structural, metamorphic, and strategic geochronological studies. On the other hand, study of the poorly exposed Narryer Gneiss Complex has relied heavily on SHRIMP within-grain zircon geochronology. In both cases the results are compatible with a terrane assembly model of crustal evolution, whereby the crust in these two regions consists of associations (terranes) of material which evolved separately prior to juxtaposition (assembly) late in the Archaean.

Diorite-tonalite-trondhjemite gneisses of Archaean gneiss complexes have geochemical and isotopic signatures which have been interpreted as evidence that they were generated at depth by subduction of mafic rocks (e.g. Martin 1986; Arkani-Hamed \& Jolly 1989), combined with predominantly hornblende fractionation during their ascent (e.g. Martin 1987). Granodiorites and granites are also present in Archaean gneiss complexes, but these have geochemical and isotopic signatures inconsistent with their representing juvenile crust formed by melting of mafic rocks (e.g. Arndt \& Goldstein 1989).

In the Godthåbsfjord region, both dioritetonalite-trondhjemite and granodiorite-granite gneiss suites are present. In the Akia and Tasiusarsuaq terranes diorite-tonalite-trondhjemite gneisses are dominant, and were emplaced into mafic volcanic rocks and gabbros. Thus these terranes contain, at least in part, juvenile (mid Archaean) crust. The Akulleq terrane of Godthåbsfjord, particularly in the Tre Brødre subterrane, is dominated by granodioritic Ikkattoq gneisses (see McGregor et al. 1991 - this volume). The geochemistry and isotopic composition of the Ikkattoq gneisses (H. Baadsgaard, pers. comm. 1988) indicates that the protoliths of these gneisses were derived at least in part from anatexis of older crustal rocks, probably including the early Archaean Amitsoq gneisses unique to the Akulleq terrane (particularly its Færingehavn sub-terrane). Therefore crustal evolution in the Godthåbsfjord region is very complex, and certainly does not represent a single CADS. Instead the terranes are samples of several major events (CADS?), in which there is evidence for both formation of juvenile crust and reworking of older sial.

In the Murchison Gneiss Association of the Narryer Gneiss Complex not only are $\sim 3300 \mathrm{Ma}$ granites important, but also most of the $\geq 3600$ Ma Meeberrie gneisses are granitic to granodioritic in composition. However, the oldest quartzofeldspathic component in the Murchison Gneiss Association is volumetrically minor $\sim 3730 \mathrm{Ma}$ tonalite mapped as part of the Meeberrie gneisses (Nutman et al. in press). In the Eurada Gneiss 
Association all the gneisses so far investigated are granitic to granodioritic in composition. In the regions adjacent to the Narryer Gneiss Complex the mid Archaean gneiss remnants range from granitic to tonalitic in composition. Thus in the Narryer Gneiss Complex and adjacent regions, granitic gneisses are much more important relative to tonalitic-trondhjemitic gneisses compared with the Godthåbsfjord region.

$\sim 3730$ tonalites of the Murchison Gneiss Association have $\varepsilon_{\mathrm{Nd} 3730}$ values of +1 to +2 (R. Maas, pers. comm. 1989; V. Bennett, pers. comm. 1990). Rare leucogabbro from this association (Myers 1988b) also yields a zircon age of $3730 \mathrm{Ma}$ (Kinny et al. 1988). This would suggest that, in the Murchison Association at least, the oldest recognised rocks could belong to a complex of tonalites intruded into basic rocks (e.g. leucogabbro) and may thus represent $\sim 3730 \mathrm{Ma}$ juvenile crust. Many of the $\mathrm{Sm}-\mathrm{Nd}$ and $\mathrm{Rb}-\mathrm{Sr}$ isotopic results reported from the Meeberrie and Dugel gneisses (e.g. De Laeter et al. 1981, 1985; Fletcher et al. 1983) are hard to interpret because they contain components of two ages, as shown by subsequent zircon work on the same samples (e.g. data in Kinny et al. 1988, 1990). Sm-Nd isotopic studies and whole rock geochemical studies are in progress on gneisses known from within-grain zircon work to consist of only one component. These will give more information on the early to mid Archaean evolution of the region.

On the basis of the relative importance of granodioritic-granitic gneisses relative to dioritictonalitic-trondhjemitic gneisses, it is evident that the processes of crustal evolution of the Narryer Gneiss Complex and the Godthåbsfjord region were somewhat different. The associations (or terranes) which form the Narryer Gneiss Complex and adjacent regions developed in settings where blocks of older continental crust were invariably present and were partially melted to form granite and granodiorite. These graniteand granodiorite-rich associations were again reworked and injected by more crustally-derived granite during final assembly in the late Archaean (Fig. 6). On the other hand, several of the gneiss suites in the terranes of the Godthåbsfjord region are dominated by juvenile crustal components at their time of formation (albeit granites unique to each terrane are also present). Sub- sequently, during terrane assembly in the late Archaean (Fig. 2) crustal melting gave rise to granites common to all terranes. By analogy with terranes in post-Archaean orogenic belts, the terranes and associations in the Godthåbsfjord region and the Narryer Gneiss Complex could have formed as the result of plate tectonic processes.

Acknowledgements - SHRIMP zircon geochronological data discussed here are contributions to the "First Billion Years" project at the Australian National University. I would like to thank my colleagues, particularly Professor W. Compston, for being able to incorporate some of these data here. The Geological Survey of Western Australia and the Geological Survey of Greenland are thanked for providing logistic help in the field. Work in Greenland was partly supported by grants from the Royal Society of London, the Carlsberg Fund, and NSERC (Canada). I thank Professor W. Compston and Drs C.R.L. Friend, P. Kinny and V.R. McGregor for discussions of this work.

\section{Dansk sammendrag}

Nyere feltobservationer og isotopiske data peger på, at Godthåbsfjord regionen $\mathrm{i}$ Vestgrønland består af et puslespil af forskellige tektoniske og stratigrafiske brikker, som havde en forskellig udvikling, før de blev bragt sammen i sen archaisk tid.

I det vestlige Australien findes Narryer gneiss komplekset. Det ligger geografisk på den nordvestlige rand af Yilgarn kratonet og er i modsætning til Godthåbsfjord området meget dårligt blottet (mindre end 1\%). Som følge heraf, er det umuligt at følge geologiske grænser i komplekset. Derfor er der gjort udstrakt brug af U-Pb dateringer af enkeltkorn af zirkon vha. ion-mikrosonde (SHRIMP). Zirkon geokronologien indicerer, at Narryer gneiss komplekset også består af flere selvstændige delområder, hvis alder er tidlig- til mellem-archaisk. I både Godthåbsfjord området og i Narryer gneiss komplekset blev den sene archaiske sammenføring af delområderne ledsaget af intrusioner af skorpe granitter, deformationer og amfibolitfacies metamorfose. Det ser altså ud til, at nogle af de archaiske, stærkt metamorfoserede gneiss komplekser gennemgik forskellig uafhængig udvikling før de blev bragt sammen senere. I denne henseende minder de om post-archaiske orogene balter, som er blevet dannet i forbindelse med pladetektoniske processer.

\section{References}

Arkani-Hamed, J. \& Jolly, W. T. 1989: Generation of Archean tonalites. Geology 17, 307-310.

Arndt, N. T. \& Goldstein, S. L. 1989: An open boundary between lower continental crust and mantle: its role in crust formation and crustal recycling. Tectonophysics 161 , 201-212.

Bohlen, S. R. 1987: Pressure-temperature-time paths and a tectonic model for the evolution of granulites. J. Geol. 95 , 617-632.

Bridgwater, D., McGregor, V. R. \& Myers, J. S. 1974: A horizontal tectonic regime in the Archaean of Greenland and its implications for early crustal thickening. Precambrian Res. 1, 179-197.

Bridgwater, D., Keto, L., McGregor, V. R. \& Myers, J. S. 
1976: Archaean gneiss complex of Greenland. In Escher, A. \& Watt, W.S. (eds) Geology of Greenland, 19-75. Copenhagen: Geol. Surv. Greenland.

Chadwick, B. \& Nutman, A. P. 1979: Archaean structural evolution in the northwest of the Buskefjord region, southern West Greenland. Precambrian Res. 9, 199-226.

Cobbold, P. R. \& Quinquis, H. 1980: Development of sheath folds in shear regimes. J. struct. Geol. 2, 119-126.

Coe, K. 1980: Nûk gneisses in the Buksefjorden region, southern West Greenland, and their enclaves. Precambrian Res. $11,357-371$.

Compston, W., Williams, I. S. \& Meyer, C. 1984: U-Pb geochronology of zircons from lunar breccia 73217 using a sensitive high mass-resolution ion microprobe. J. geophys. Res. 89, supplement B, 525-534.

Compston, W. \& Pidgeon, R. T. 1986: Jack Hills, evidence of more very old detrital zircons in Western Australia. Nature 321, 766-769.

Coney, P. J., Jones, D. L. \& Monger, J. W. H. 1980: Cordilleran suspect terranes. Nature 288, 329-333.

De Laeter, J. R., Fletcher, I. R., Rosman, K. J. R., Williams, I. R., Gee, R. D. \& Libby, W. G. 1981: Early Archaean gneisses from the Yilgarn Block, Western Australia. $\mathrm{Na}$ ture 292, 322-324.

De Laeter, J. R., Fletcher, I. R., Bickle, M. J., Myers, J. S., Libby, W. G. \& Williams, I. R. 1985: Rb-Sr, Sm-Nd and $\mathrm{Pb}-\mathrm{Pb}$ geochronology of ancient gneisses from Mount $\mathrm{Nar}$ ryer, Western Australia. Aust. J. Earth Sci. 32, 349-358.

Dymek, R. F. 1984: Supracrustal rocks, polymetamorphism, and evolution of the SW Greenland gneiss complex. In Holland, H. D. \& Trendall, A. F. (ed.) Patterns of change in Earth evolution, 313-343. New York: Springer-Verlag.

Fletcher, I. R., Williams, S. J., Gee, R. D. \& Rosman, K. J. R. 1983: $\mathrm{Sm}-\mathrm{Nd}$ model ages across the margins of the Archaean Yilgarn block, Western Australia; northwest transect into the Proterozoic Gascoyne Province. J. geol. Soc. Aust. 30, 167-174.

Friend, C. R. L. \& Nutman, A. P. 1988: Evolution and emplacement of Archaean terranes in the Kapisigdlit area, southern West Greenland. Rapp. Gronlands geol. Unders. $140,59-64$.

Friend, C. R. L., Nutman, A. P. \& McGregor, V. R. 1987: Late-Archaean tectonics in the Færingehavn-Tre Brødre area, south of Buksefjord, southern West Greenland. $J$. geol. Soc. Lond. 144, 369-376.

Friend, C. R. L., Nutman, A. P. \& McGregor, V. R. 1988: Late Archaean terrane accretion in the Godthåb region, southern West Greenland. Nature 335, 535-538.

Froude, D. O., Ireland, T. R., Kinny, P. D., Williams, I. S., Compston, W., Williams, I. R. \& Myers, J. S. 1983: Ion microprobe identification of 4,100-4,200 Myr-old terrestial zircons. Nature 304, 616-618.

Fyfe, W. S. 1973: The granulite facies, partial melting and the Archaean crust. Phil. Trans. R. Soc. Lond. A273, 457-461.

Gee, R. D., Baxter, J. L., Wilde, S. A. \& Williams, I. R. 1981: Crustal development in the Archaean Yilgarn Block, Western Australia. Spec. Publ. geol. Soc. Aust. 7, 43-56.

Grant, N. K. \& Hickman, M. H. 1984: Rb-Sr systematics and contrasting histories of late Archean gneisses, West Greenland. Geology 12, 599-601.

Kinny, P. D. 1987: Uranium-lead and hafnium isotopes in zircon. Unpubl. Ph. D. thesis, Australian National University, Canberra. $160 \mathrm{pp}$.

Kinny, P. D., Williams, I. S., Froude, D. O., Ireland, T. R. \& Compston, W. 1988: Archaean zircon ages from orthogneisses and anorthosites at Mount Narryer, Western Australia. Precambrian Res. 38, 325-341.

Kinny, P. D., Wijbrans, J. R., Froude, D. O., Williams, I. S. \& Compston, W. 1990: Age constraints on the evolution of the Narryer Gneiss Complex, Western Australia. Aust. J. Earth Sci. 37, 51-69.

Kusky, T. M. 1989: Accretion of the Archean Slave Province. Geology 17, 63-67.

Martin, H. 1986: Effect of steeper Archean geothermal gradient on geochemistry of subduction-zone magmas. Geology 14, 753-756.

Martin, H. 1987: Petrogenesis of Archaean trondhjemites, tonalites and granodiorites from eastern Finland: major and trace element chemistry. J. Petrology 28, 921-953.

McGregor, V. R. 1973: The early Precambrian gneisses of the Godthåb district, West Greenland. Phil. Trans. R. Soc. Lond. A273, 343-358.

McGregor, V. R. 1979: Archean gray gneisses and the origin of the continental crust: evidence from the Godthảb region, West Greenland. In Barker, F. (ed.) Trondhjemites, dacites and related rocks, 169-204. Amsterdam: Elsevier.

McGregor, V. R., Bridgwater, D. \& Nutman, A. P. 1983: The Qârusuk dykes: post-Nôk, pre-Qôrqut granitoid magmatism in the Godthåb region, southern West Greenland. Rapp. Gronlands geol. Unders. 112, 101-112.

McGregor, V. R., Nutman, A. P. \& Friend, C. R. L. 1986: The Archean geology of the Godthåbsfjord region, southern West Greenland. In Ashwal, L.D. (ed.) Workshop on early crustal genesis: the world's oldest rocks. Lunar planet. Inst. tech. Rep. 86-04, 113-169.

McGregor, V. R., Nutman, A. P. \& Friend, C. R. L. 1991: The late Archaean mobile belt through Godthåbsfjord, southern West Greenland: a continent-continent collision zone? Bull. geol. Soc. Denmark (this volume).

Moorbath, S. \& Pankhurst, R. J. 1986: Further rubidiumstrontium age and isotope evidence for the nature of the late Archaean plutonic event in West Greenland. Nature $262,124-126$.

Moorbath, S. \& Taylor, P. N. 1986: Geochronology and related isotope geochemistry of high grade metamorphic rocks from the lower continental crust. Spec. Pap. geol. Soc. Lond. 24, 211-220.

Moorbath, S., Taylor, P. N. \& Jones, N. W. 1986: Dating the oldest terrestial rocks - fact and fiction. Chem. Geol. 57, 63-86.

Myers, J. S. 1988a: Early Archaean Narryer Gneiss Complex, Yilgarn Craton, Western Australia. Precambrian Res. 38, 297-307.

Myers, J. S. 1988b: Oldest known terrestial anorthosite at Mount Narryer, Western Australia. Precambrian Res. 38, 309-323.

Myers, J. S. \& Williams, I. R. 1985: Early Precambrian crustal evolution at Mount Narryer, Western Australia. Precambrian Res. 27,153-163.

Nutman, A. P., Friend, C. R. L., Baadsgaard, H. \& McGregor, V.R. 1989: Evolution and assembly of Archean gneiss terranes in the Godthåbsfjord region, southern West Greenland: structural, metamorphic and isotopic evidence. Tectonics 8, 573-589.

Nutman, A. P., Kinny, P. D., Compston, W., \& Williams, I. S. in press: SHRIMP U-Pb zircon geochronology of the Narryer Gneiss Complex, Western Australia. Precambrian Res.

Pidgeon, R. T. 1986: The correlation of acid volcanics in the Archaean of Western Australia. Western Aust. Mining Petrol. Res. Inst. Rep. 27, $102 \mathrm{pp}$.

Robertson, S. 1986: Evolution of the late Archaean lower continental crust in southern West Greenland. Spec. Publ. geol. Soc. Lond. 24, 251-260.

Schiøtte, L., Compston, W. \& Bridgwater, D. 1989: U-Pb single-zircon age for the Tinissaq gneiss of southern West Greenland: a controversy resolved. Chem. Geol. 79 (Isotope Geosci. Sect. 10), 21-30. 
Sibson, R. H. 1977: Fault rocks and fault mechanisms. J. geol. Soc. Lond. 133, 191-213.

Taylor, P. N., Moorbath, S., Goodwin, R. \& Petrykowski, A. 1980: Crustal contamination as an indicator of the extent of early Archaean continental crust: $\mathrm{Pb}$ isotopic evidence from the late Archaean gneisses of West Greenland. Geochim. Cosmochim. Acta 44, 1437-1453.

Wells, P. 1976: Late Archaean metamorphism in the Buksefjorden region of southwest Greenland. Contrib. Mineral. Petrol. 56, 229-242.

Wells, P. R. A. 1979: Chemical and thermal evolution of Ar- chaean sialic crust, southern West Greenland. J. Petrology $20,187-226$.

Wells, P. R. A. 1980: Thermal models for the magmatic accretion and subsequent metamorphism of continental crust. Earth planet. Sci. Lett. 46, 253-263.

Williams, I. R. \& Myers, J. S. 1987: Archaean geology of the Mount Narryer region, Western Australia. Rep. West. Aust. Geol. Surv. 22, 32 pp.

Williams, S. J. 1986: Geology of the Gascoyne Province, Western Australia. Rep. West. Aust. Geol. Surv. 15, 85 pp. 